\title{
Um bilingüismo clandestino. A presença iídiche em Tempos prodigiosos, de Aharón Appelfeld
}

Perla Sneh

\section{Ideologia e escritura}

Nunca - nem nos distantes tempos bíblicos - os judeus se conformaram com uma única língua. Se bem o hebraico sempre foi sua língua fundamental - língua santa reservada à leitura das Escrituras e sua interpretação -, esta sempre conviveu - com melhor ou pior sorte - com outras línguas de uso cotidiano às quais o hebraico empresta seu alfabeto como traço de especificidade.

A multiplicidade das línguas judaicas, proliferadas na errância da diáspora, talvez seja uma colocação em ato na própria fala de um paradoxo do judaísmo: havendo introduzido na cultura o monoteísmo, não supõe, no entanto, uma única autoridade interpretativa. A palavra não diz uma coisa só: o monoteísmo judaico é multilíngüe.

Da multiplicidade de línguas judaicas, o iídiche - talvez a língua judaica por excelência ${ }^{1}$ - teve um destino singular. Até o dia de hoje, essa língua, falada em algum momento por cerca de doze milhões de pessoas, costuma ser considerada pela opinião popular apenas uma corruptela do alemão moderno ou uma deformação do hebraico. ${ }^{2}$ No entanto, sua história, rica em vicissitudes, remonta aos séculos X e XI e recolhe os ecos de uma pré-história que navega entre a Judéia e o Império Bizantino, para atravessar a Idade Média e germinar - em torno do fim do século XIX - em uma língua impetuosa, na qual se fundem elementos hebraicos, românicos, germanos e eslavos, que dá lugar a uma impressionante literatura. Mas a noite nazista veio interromper essa história, ao exterminar grande parte de seus falantes. E, embora o ídiche tenha persistido por algum tempo - fora da Europa, especialmente nos Estados Unidos e na América Latina ${ }^{3}$-, com o tempo deixou de ser o que era: uma língua da vida cotidiana.

Mas não é para a história do iídiche que se voltam estes escassos parágrafos, mas sim para situar sua estranha atualidade. Pois o iídiche, língua que ao longo de sua história nunca alcançou soberania nem comandou forças militares, língua que foi declarada em 1908 língua nacional paralelamente ao hebraico, ${ }^{4}$ que sempre carregou a marca do desprezo por seu caráter de língua impura, de língua estrangeira por antonomásia, tornou-se, na atualidade, objeto de devoção quase religiosa - talvez como compensação pelo desprezo que este zhargon ${ }^{5}$ outrora despertara -, adquirindo uma estranha existência virtual junto a um reconhecimento acadêmico impensável há trinta ou quarenta anos.

A vida do iídiche nunca foi fácil, nem sequer em seus momentos de glória, momentos que coincidem com uma das Kulturkampf de mais amplo alcance na história dos judeus: o desdobramento da Haskalá ${ }^{6}$ paralelo à difusão de um peculiar movimento de massas como foi o Jasidismo. ${ }^{7}$ Uns e outros se encontraram nessa combustão que significou o encontro - o choque - das línguas judaicas com as linguagens da modernidade, combus- 
tão alimentada também pelos grandes movimentos sociais, os nacionalismos europeus e pelo ressurgimento nacional judaico: o sionismo.

Com o tempo - e não sem os avatares de destruição e renascimento que o século XX reservou para o povo judeu - a relação iídiche/hebraico veio a ser a assim chamada "grande guerra judaica pela linguagem", 8 e o tradicional bilingüismo judaico ficou intolerável no caso do iídiche. O debate iídiche/hebraico tornou-se emblema do conflito sionismo/diáspora.

Já em torno da Primeira Guerra Mundial, o iídiche e o hebraico começam a perder a complementaridade estilística (em iídiche se conversa, em hebraico se pensa; o í́diche é narração; o hebraico, ensaio), embora se estabeleça uma complementaridade geográfica: hebraico é Palestina, iídiche é a Diáspora, a sujeição ao poderoso, a miséria do shtetl. ${ }^{9} \mathrm{~A}$ exigência de opção - que traduzia o fragor ideológico da hora - foi instalando o estereótipo da oposição pura e simples.

No entanto, essa oposição se sustentava na ideologia, não na escritura. E assim Shólem Aleijem ${ }^{10}$ - um dos grandes nomes da literatura iídiche moderna - declara-se sionista, enquanto Itzjok Leibush Péretz, ${ }^{11}$ que além de escrever em iídiche o faz em hebraico (insuflando-lhe um inédito ar moderno), não o é. Um escritor como Hillel Tzeitlin pode sustentar a defesa do judaísmo rabínico (oposto ao jasidismo) em iídiche (a língua dos jasidim), enquanto o poeta Abraham Sutzkever pode viver toda a sua vida em Israel escrevendo somente poesia iídiche. Ou, para mencionar um caso dramático, podemos citar Uri Tzvi Grinberg, poeta iídiche em Varsóvia até que em 1923 se despede da Diáspora com seu poema In land fun tžeilem - Na terra da cruz - e parte rumo à Palestina, onde se une aos sionistas ultranacionalistas que, nesses dias, levavam adiante a batalha contra o iídiche. Finalmente, digamos que em 1927, quando surge a proposta de criar um Departamento de Iídiche na flamejante Universidade Hebraica de Jerusalém, é precisamente Jaim Najman Bialik - poeta nacional bebreu - que se declara a favor.

Porém, a ideologia terminou por carcomer a escritura, e a criação do Estado de Israel esteve imersa em um amargo debate sobre a língua nacional, debate que vai plasmando seus próprios mitos fundadores. Um deles é o "mito cananeu" - cuja figura central é o poeta Yonatan Ratosh - que pretende renunciar por completo aos conteúdos judaicos da vida em Israel. A literatura se debruça sobre uma experiência israelense $s a b r a,{ }^{12}$ com paisagens locais, histórias do presente israelense, vivências de combate e de ressurgimento nacional. Surge assim a figura do israelense que se livrou do peso judeu: um jovem alto e bronzeado que se opõe à figura curvada do ancião judeu da Diáspora, um novo ser que não carrega o julgo da tradição. Como diz a frase de abertura de um romance emblemático do momento: "Elik surgiu do mar", ${ }^{13}$ um homem novo, surgido da natureza. E a língua de Elik exigirá a ele "esquecer tudo e não recordar nada". ${ }^{14}$ Este cego afã de ruptura, expresso sobretudo na recusa da própria língua da Diáspora, denuncia, no entanto, o peso que tem sobre essa inicial escritura hebraica a relação com seu legado.

Assim, será nessa mesma realidade que uma escritura judaica, hierosolimitana, moderna, parte - sem envergonhar-se - em busca do tempo perdido nas aldeias européias: a de Shmuel Yosef Agnon, que, com o tempo, será mentor de uma geração de escritores israelenses que encontrarão em sua escritura um novo mito de fundação: o "mito judaico". 
A esse mundo de línguas desgarradas - onde as palavras rejeitadas não deixam de pesar até no próprio nome ${ }^{15}$ - chega, aos catorze anos, Aharón Appelfeld, que, nessa época, não falava quase nenhuma língua, embora "balbuciasse em todas". ${ }^{16}$

\title{
II. Um bilingüismo clandestino
}

\author{
You don't speak a mother tongue, it just flows out of you. \\ With an acquired language, you must be on constant watch, \\ guarding it from foreign intrusions. Until this day I fear \\ the language will get lost. Sometimes I wake up, and it \\ seems that the Hebrew, the language I acquired with \\ great effort, fades away, disappears. ${ }^{17}$ \\ Aharón Appelfeld
}

Appelfeld nasceu em Czernowitz (Bucovina), em 1932. Aos oito anos, a guerra contra os judeus o atinge. Deportado para um campo de concentração, consegue escapar. Passa os anos que restam da guerra escondido nos bosques e convivendo com pessoas do submundo, gente que não faz muitas perguntas. Seus olhos azuis e seu cabelo loiro servem de precário "certificado de arianidade", uma precariedade que deve reforçar mantendo a boca fechada: as palavras poderiam traí-lo e revelar sua condição de judeu.

Quando criança, falava o ostentoso alemão do Império Austro-Húngaro - língua que sua mãe amava -, conhecia o iídiche de seus avós que os pais repudiavam, sabia alguma coisa de ucraniano - aprendido de uma criada a quem dedicou um amor infantil e alimentado no submundo da guerra - e algo de ruteno, mas não falava quase romeno, língua oficial da região desde que, alguns anos antes, a Bucovina havia sido anexada à Romênia. ${ }^{18}$ Recolhido, mais tarde, pelo exército soviético, incorpora algo de russo. Acrescentemos a essas línguas a do barulhento silêncio do bosque no qual sobreviveu escondido.

Ao chegar a Israel (então Palestina), quase não possuía vocabulário. O hebraico que o rodeava lhe parecia um idioma duro, uma linguagem de "soldados camponeses"; o ar soava como um discurso complicado, pleno de consoantes cortantes e de slogans - anu banu artza libnot u'lebibanot ba (chegamos a nossa terra para construí-la e construirmo-nos nela) -, as palavras soam-lhe como ordens e não lhe servem para responder sua maior incógnita: o que lhe havia acontecido? Sabia que havia tido uma vida, sabia que esta havia explodido, mas não dispunha das palavras para dizer isso.

Nesse barulhento vazio de palavras alheias, "surgiu da escuridão um homem com uma pequena lanterna, que somente parecia querer estabelecer uma conversa casual': ${ }^{19}$ Dov Sadán, ${ }^{20} \mathrm{com}$ quem aprende o iídiche, a língua de seus avós, a língua de um mundo que havia entrevisto de longe na paisagem de sua infância, onde o judeu não era senão relíquia constrangedora do passado.

Se mencionamos esses mínimos detalhes não é para cometer impertinência biográfica, mas sim para situar a experiência lingüística na qual se arraiga uma escritura que vacila na hora de buscar refúgio em uma língua que flui. Nessa vacilação, Appelfeld - que não hebraizou seu nome, como o exigia a ideologia do momento - "estuda o ídiche, mas adota o 
hebraico como língua própria", como se o recurso ao iídiche lhe houvesse permitido fazer as pazes com o caráter cortante do hebraico, como se para falar hebraico tivesse precisado de outra língua. Mas sua escritura - elegante, precisa, biblicamente poética em seu laconismo - sugere uma relação com o hebraico muito mais intensa que um mero armistício, sugere o estranho prodígio de falar o silêncio de uma língua nas vozes de outra.

É essa escritura, a de um hebraico que se tornou possível pela via do iídiche - ou seja, uma língua secreta, clandestinamente bilíngüe - a que queremos percorrer aqui em um de seus muitos romances: Tor Ha'Plaot - O tempo dos prodígios. ${ }^{21}$

\section{Tor Ha Plaot - Tempos prodigiosos}

Tempos prodigiosos - talvez o texto central da aventura literária de Appelfeld ${ }^{22}$ - cai, como toda a sua obra, no que o furor interpretandis da crítica especializada costuma chamar "literatura da Shoah". No entanto, o próprio Appelfeld, com sutileza mallarmeana ${ }^{23}-$ se esquiva dessa atribuição: "são as palavras" - diz - "e não o tema o que constrói um texto". ${ }^{24}$

E, de fato, se a Shoah está presente no horizonte de suas palavras, no texto só está sob a forma de sua ausência, uma ausência destacada com precisão pela página em branco que separa a primeira parte - Tempos prodigiosos - da segunda - No fim das contas e depois de muitos anos.

São dois momentos: no primeiro, um menino fala em primeira pessoa de seus anos de infância burguesa com uma mãe amorosa e um pai distante, anos que terminam com o abandono do pai e a deportação do menino e sua mãe. No segundo, o menino - agora adulto e mencionado por seu nome, Bruno - regressa ao povoado muitos anos depois. Entre ambos os momentos, soa essa página em branco, sem palavras mas não sem voz. Porque embora a Shoah como tal fique como página em branco na narração, o que aparece com insistente recorrência é uma presença que se tornou emblema da matança: tudo começa e termina em um trem, um trem que se ouve desde o compassado movimento do começo até a iminência do apito final: "Há muitos anos voltávamos de trem, mamãe e eu, de um balneário belo mas desconhecido..." (p. 7) - são as palavras iniciais da primeira parte, que termina quando o menino e sua mãe partem "confinados no trem de carga que fazia velozmente seu caminho em direção ao sul' (p. 132).

A segunda parte também começa com um regresso de trem, o desse mesmo menino narrador que já não fala em primeira pessoa - "Bruno viajava de volta [...]. O trem avançava velozmente em direção ao norte” (p. 135) -, e haverá de concluir na estação de trem, quando Bruno está para partir novamente:

- Quando chega o trem? - perguntou.

- Às seis - disse-lhe a mulher da banca.

- Costuma ser pontual?

- Em geral.

[...] Sem perceber seus olhos se fixaram no sinal, na espera de que a chapa de estanho se precipitasse para baixo e o apito da locomotiva lhe abrisse o caminho (p. 206). 
A narração chega até aí e se interrompe, esperando esse apito, essa voz que às vezes é grito, às vezes silêncio, às vezes só "uma espécie de assombro" (TP, 106).

O trem é, sem dúvida, a cara maquinal da matança, uma cara que se anuncia já nos primeiros parágrafos - "Era um vagão reservado [...] A porta estava aberta e no vão se destacava uma moça [...] De repente, como movida por um mecanismo externo, começou a servir café e torta de queijo" (TP, 7) -, e que haverá de acentuar-se ao longo do texto, em uma ordem cada vez mais indecifrável de horários e acessos:

Pararia aqui o expresso? O chefe da estação, já instalado em seu lugar, respondeu, às vezes sim, às vezes não. Depende das instruções da central.

- E o senhor, não interfere de nenhuma forma?

- Não (p. 57).

No entanto, o trem, essa espécie de não-lugar ao qual ciclicamente retornam ou em que se vêem lançados os personagens em peregrinações mais e mais absurdas, é, além de emblema da matança, o âmbito por excelência do iídiche. O trem é cenário obrigatório de incontáveis contos e anedotas, é onde tantos falam essa língua de diálogo e encontro. É no trem que os judeus europeus - reais e literários - se encontram, vociferam, falam até pelos cotovelos.

E é precisamente no trem onde, com sutil ironia, Appelfeld põe na boca dos judeus que se pretendem distanciados da língua constrangedora, uma série de diálogos dignos de Shólem Aleijem. ${ }^{25}$ Por exemplo, o que mantém um casal - alterado pelo "estrépito judeu" - quando o tom idilicamente melancólico do começo da nar ração se vê interrompido pela lenta mas segura parada do trem para que "todos os cidadãos estrangeiros, assim como os cidadãos austríacos que não sejam cristãos de nascimento, hajam por bem registrar-se no escritório que acaba de ser legalizado...".

- Por que você não vai perguntar?

- O que tem que perguntar? Um defeito.

- Bem, o que você quer é que eu faça isso por você.

- [...] O lugar não é mais do que uma estância abandonada. Que outra informação você quer de

mim?

- Por que parou [o trem]?

- Porque a locomotiva parou de andar (10).

E depois:

- O que você quer, então?

- Quero que você faça uma reclamação.

- Entendo. Você quer que eu faça um escândalo.

- Faça o que você quiser. Não estou com vontade de discutir (10).

Ou o que deverá manter, mais adiante (p. 57), o pai do narrador com um guarda:

- Se ninguém vive aqui e não há hotéis, por que o trem pára aqui?

- Você pergunta pra mim - espantou-se o guarda.

- Pra quem você queria que eu perguntasse? 
- Você tem todo o direito de me perguntar, é claro, mas não espere que eu responda.

Esse tom irônico - de inequívoca filiação iídiche - estende-se pela escritura como uma espécie de suave baixo-contínuo.

É o tom que fará dos Habsburgo, cifra da venerada herança cultural recém-adquirida, o pomposo nome de uma pequena rua com pretensões de boulevard em um pequeno povoado burguês da infância: Ha'Shderá Ha'babsburguit (Avenida dos Habsburgo). Ou o que faz do nome de Masaryk ${ }^{26}$ - paradigma da aspiração iluminista - o absurdo domicílio de um pai alucinado que abandonou o lar e se consome vociferando "sou um escritor austríaco", enquanto sopram, inequívocos, os ventos da destruição. ${ }^{27}$

É o tom que insiste no aparatoso título da "Comissão de Estímulo à Criação Literária [...] uma comissão muito respeitável e reconhecida pela retidão de seu julgamento. Na última sessão, houve diferenças de opinião e papai ameaçou renunciar. A comissão resolven adiar a decisão para uma próxima sessão" (69). Quem está familiarizado com a literatura í́diche não pode deixar de entrever aqui a multidão de "comissões" semelhantes que povoam as histórias de Kasrílevke, ${ }^{28}$ caracterizadas por veementes diferenças de opinião, ameaças de renúncia e a invariável resolução de adiar a resolução até a próxima sessão.

É no hospício judaico de Paul Gutsman ${ }^{29}$ onde se interna o escultor Stark, um meio-judeu que decide abraçar o judaísmo - para tanto, deve cumprir "esses costumes bárbaros que exigiam do homem um talho de seu corpo" (93), que tanto exasperam o pai-, que a ironia ganha um viés grotesco. A narração menciona o lugar, no início, como beit-majasé - termo hebraico composto: casa de refúgio. Nesse "refúgio", o pai, escandalizado com a miséria do lugar, exige falar com os responsáveis, que o olham com sorna, até que um deles decide chamar as coisas por seu nome:

- O que é isto? - papai ficou quieto em seu lugar.

- Está perguntando o que é isto, explicou um a seu colega.

- Isto é um hekdesh judaico, um hekdesh. Por acaso não conhece esta instituição?

É uma Instituição antiga, tradicional. Por acaso não é conhecida na Áustria? (86)

Não se trata, então, de um "refúgio" ou um "abrigo" em sentido genérico - beit majasé - mas sim de um hekdesh, um hekdesh iehudi (um hekdesh judaico). O hekdesh (voz hebraica que originalmente se refere ao consagrado ao Templo) nomeia - em í́diche - o hospital comunitário que também servia de abrigo para os pobres da cidade e para os mendigos errantes que passavam por ela. É uma instituição social característica da organização social do shtetl, ${ }^{30} \mathrm{em}$ que a figura do curandeiro prevalece sobre a do médico. ${ }^{31}$

Sendo assim, acrescentar iehudí - judaico - a hekdesh não é nada mais que uma redundância irônica dirigida ao interlocutor, que não vê nada, que não quer ver nada. A mesma ironia soa nos termos hebraicos com que nomeia a "instituição" " Por acaso não conbece esta instituição? É uma instituição veterana, tradicional. Por acaso não é conhecida na Austria?').

Na primeira menção, utiliza a palavra mosad, termo de raiz hebraica, enquanto da segunda vez - precisamente quando relaciona a instituição com a tradição - utiliza, ironicamente, um termo de cunho universal: institutzia. 
Não é por acaso que seja diante dessa cegueira e nesse âmbito que o texto põe em cena esses corpos abandonados que, "com a cabeça raspada e pijamas listrados", desesperam da palavra: "- Não desperdice palavras - disse o velho do pijama listrado" (p. 85).

Esse tom de sutil ironia pode subir ou baixar no ir-e-vir da escritura, mas nunca chega a resolver-se em franca sátira - gênero iluminista por excelência ${ }^{32}$-, embora, sim, vá construindo, como em filigrana, como um indício para o ouvido atento, um personagem fundamental da mesma: o shlemazl.

O termo - fruto da combinação de uma palavra germânica, schlimm (má), e uma hebraica, mazal (sorte) - alude a um personagem que se acredita no controle do mundo que o rodeia, mas que se revela ao olhar do outro como um bobo que não tem controle sobre nada; uma espécie de bufão, vítima da desgraça que "nunca percebe os sinais do perigo". ${ }^{33}$

Essa figura, recorrente na literatura e sobretudo no teatro í́diche, adquire em Tempos prodigiosos originalidade própria: trata-se de um shlemą̧ que impressiona por seu impecável sotaque austríaco, que se equipara com os grandes nomes da cultura, que agita todos e cada um dos emblemas da civilização; em suma, um shlemazl ilustrado. A mesma candidez, a mesma ingênua soberba, mas, isso sim, com uma pronúncia impecável.

São várias as cenas que transitam por essa mistura absurda de candidez e soberba, mas chegam a uma espécie de clímax no capitulo X, quando tudo ao redor diz "transtorno dos sentidos, desespero alegre e amargo cheiro do fim que se aproxima", e o pai decide "pôr fim à hostilidade que ia nos cercando" (90). Para isso se dispõe a visitar, junto com sua mulher e seu filho, um antigo camarada de estudos, um nobre austríaco chamado Dauber. A candidez desse shlemazl ilustrado se impõe com tal força que arrasta a todos, até ele mesmo: diante do trem cheio de civis e soldados, fica "sem forças para dizer: "Voltemos".

E será, de novo, no trem - pela primeira vez de terceira classe - onde se põe a nu um olhar implacável, ${ }^{34}$ essa "espécie de espreita" (54) que inunda a narração desde o começo e que o shlemazl evita registrar:

Essa viagem precipitada não era senão um encontro com uma lucidez diferente [...] Todos sabíamos que éramos judeus que pretendiam passar por austríacos [...] Papai, que no começo tratou de negar nossa vergonhosa origem, acabou reconhecendo que éramos judeus, mas não comerciantes judeus. [...] No portão da fazenda, papai apresentou-se como um velho amigo do príncipe [...] O porteiro, impressionado com a pronúncia austríaca, sentiu-se constrangido por ter que dizer que a essa hora da manhã o príncipe estava dormindo.

Permanecem o dia inteiro na guarita do porteiro, que telefona várias vezes para a mansão para pedir instruções até que, no último telefonema, escuta algo que ensombra seu rosto. Então o pai decide regressar. Saúda o porteiro, mas este não responde. "Temia complicar-se".

No trem de regresso, uma mulher reconhece o pai; havia lido seus livros. Ressurgem agora os grandes nomes: S. Zweig, Wasserman, Schnitzler, o grupo de Praga e o grupo de Viena e, evidentemente, o de "um escritor que dará muito o que falar no futuro, Franz. Kafka". Mas "não lhe menciona a fazenda de Dauber". Somente se mostra ansioso por regressar "para completar vários capitulos de seu novo livro". 
Essa exacerbação do shlemą̧l ilustrado será o prelúdio dos últimos dias, quando a casa se enche de "rostos perdidos que trazem aceso o tição dos trens", quando a mãe, de repente, deixa de falar - "como se as palavras tivessem se perdido dela e eu dentro delas", diz o menino; quando o pai abandona o lar e o filho chega à idade de seu Bar Mitzvá, ${ }^{35}$ treze anos: "Mamãe perguntou se não era o caso de consultar o rabino. Pareceu-me estranho. Seus pés jamais haviam pisado um recinto de culto" (126).

Agora é a mãe que vai bater em uma porta que não se quer abrir: o rabino pergunta pelo sobrenome "com palavras encobertas, como se fôssemos suspeitos". As palavras não conseguem comovê-lo: a casa "não é digna de chamar-se uma casa judaica". No entanto, poucos dias depois, recebem uma carta dizendo "que todos os membros da comunidade deviam apresentar-se na terça-feira às cinco no Templo".

E na aceleração do fim, assim como o pai - escritor austríaco de pronúncia impecável - inteira-se da enorme distância que o separa das palavras que acredita serem suas por direito próprio, o menino e a mãe se inteiram do que sempre souberam sem saber que sabiam: "Não sabiamos quão curto era o caminho da casa até o Templo" (TP, 129).

No final desse caminho, somente encontrarão o peso insuportável das palavras que se fincam em seus corpos:

\footnotetext{
As palavras estrondavam agora em sua boca [...] Velhas palavras que outrora serviram para diferentes necessidades, flutuavam no ambiente como fuligem... E entre as palavras amargas houve algumas que se fincaram em nós, em nossa secreta desgraça, como pregos (131) [...] Um silêncio de depois de tudo se estendeu sobre as pessoas sentadas no chão. Ninguém voltou a dizer "Você"... (TP, 130-131).
}

E com as palavras cravadas no corpo saem de cena no trem: "No dia seguinte já estávamos confinados no trem de carga que corria para o sul'.

\section{No fim das contas e depois de muitos anos}

Entre a primeira e a segunda parte há uma página em branco. O que se segue à página em branco outra vez nos põe em um trem, outra vez faz soar o "estrépito judaico": um judeu baixinho "arranhava alemão com sotaque estrangeiro". A esse corpo que gesticula e envergonha, Bruno - que agora vive em Jerusalém, ou seja, que fala hebraico - diz: "Não entendo".

E se a resposta surge da antiga rejeição, também é certo que Bruno não mente: ele perdeu as palavras, perda que já se anunciava no distante começo da primeira parte. "E se no início ainda revoavam entre nós algumas palavras, estas foram se apagando e já não ressurgiram mais" (p. 12).

As palavras serão no romance aquelas que carregam as marcas da história, mas não a palavra como unidade lingüística, e sim como a própria matéria do corpo e da memória, palavras escritas em uma língua à qual se acedeu por recurso a outra.

Mas como fazer ressoar a verborréia do iídiche na estrita economia do hebraico? $\mathrm{O}$ iídiche haverá de infiltrar-se no hebraico da narração não como palavras mencionadas ou 
traduzidas, mas como marcas no plano da própria estrutura da língua, daí a inversão freqüente no texto - da ordem da frase, inversão muito comum na sintaxe í́diche:

Nos'im ajerim, sablanutám pak'á (Outros passageiros, sua paciência se esgotou)

... agrá ima milim... (amontoou mamãe palavras) (p. 48)

... nevojim amadnu... (confusos ficamos) (p. 49)

Ou o recurso à repetição:

... não faria um culto biológico de um simples fenômeno biológico... (TP, 105)

Pela primeira vez senti sobre mim o olhar do caçador. [...] Quis o azar que não houvesse outro lugar disponível senão junto ao caçador que nos caçou com o primeiro olhar (TP, 108)

Mas, sobretudo, a voz do iídiche está presente nessa maneira como o texto faz das palavras as verdadeiras protagonistas, detendo-se em seus tons, seus matizes, seus silêncios:

... tratou de verter palavras em seu olhar... (TP, 10)

As palavras se esgotaram dentro de mim (TP, 43)

... regressaram meus pais (...) trazendo consigo uma rajada de estranha algaravia, palavras que, parecia, haviam adquirido ali (TP, 43).

A linguagem de papai soava refrescante aos meus ouvidos, com palavras claras e muito compreensíveis [...] e mamãe acrescentava em seu falar sempre tímido, como se não estivesse segura de seus modos... (TP, 47)

Palavras envolvidas em fumaça e vapores alcoólicos competiam entre si... (TP, 75)

Palavras iracundas como antes não havia na casa, serravam o âmbito entre um riso e outro, como grasnidos de corvo (TP, 76).

Não havia força nessas palavras, somente dor nua (TP, 92).

Papai tratou de animar-nos com velhas palavras... (108)

Palavras que, nesta segunda parte, se tornam sensações: um frio no peito, um sabor amargo na boca, um reflexo pálido mas palpável, enfiando um passado que se nega à compulsão da memória mas se debulha em mínimas recordações corporais. Cada palavra é uma cicatriz e cada cicatriz, uma lembrança no corpo:

As palavras simples, familiares, das quais não se servira durante tantos anos, tocaram-no como com água fria (TP, 139)

Todos esses pequenos detalhes [...] como se não houvessem sido fatos esquecidos mas sim sensações palpitantes (TP, 159)

Afloraram em sua língua palavras que não havia usado durante anos e o encontro com as palavras que havia conservado dentro dele o alegrou (TP, 146)

Palavras insólitas, novas, e com um matiz de embriaguez (TP, 184)

Bruno as conhecia como às cicatrizes de seu corpo (TP, 138)

As palavras são cicatrizes de corpos cujo destino a narração havia antecipado: "Tio Karl, com cujo nome existiu em um tempo um importante prêmio literário, surpreendeu a família ao chegar seu corpo à ciência. Mas [...] seu cadáver foi cremado" (TP, 89). 
Serão as palavras/cicatrizes que diferenciarão os judeus - termo que quase não aparece em todo o romance, salvo como expressão despectiva ou irônica - daqueles que não o são e que mantêm uma relação "natural" com uma língua de poucas palavras, as mesmas para tudo.

"Não sei, não perguntei, fiquei com vergonha, acreditei nele" - diz Yetti, a camponesa enganada que chega a casa com uma criança nos braços - "Esse era todo o seu vocabulário" (TP, 75). "... Seu vocabulário não havia aumentado" (TP, 76).

Lonka, a dona de um café, tem uma boca que está "a ponto de explodir em palavras duras" (TP, 156). "Dos judeus falava em segredo, com ar sedutor. [...] ... seu marido [...] impôs um falar rude e aos gritos" (157).

De Helga, uma menina que a mãe - em um ímpeto de furor solidário - traz do Lar dos Expostos, diz: "Logo aprendi que tinha suas próprias palavras, palavras que a faziam rir e palauras que faziam aflorar em seus lábios um fio de astúcia" (TP, 120).

Diz Hil, uma "mestiça" (ou seja, com alguma ascendência judaica): "Papai dižia que a vovó tinha suas próprias palavras" (149). E Bruno sabe que ela "não tinha muitas palavras e com as mesmas falava com todos".

Mas, como os corpos mortos que vivem, a palavra também é espectral. Esta é a palavra que haverá de primar no encontro com Brum, figura de nome vago e inquietantemente semelhante, que conservou o olhar do caçador em seus olhos. Uns olhos que, em um tempo, haviam sido outros e haviam alcançado uma "transformação perfeita":

\footnotetext{
Naqueles dias aziagos, no último ano que precedeu a expulsão, nessa tremenda confusão, em que as pessoas se convertiam a outra fé, vendiam lojas, abandonavam mulheres amadas, se drogavam com álcool, naqueles dias Brum tomou por esposa a empregada da casa. Em poucas semanas, produziu-se o milagre. Brum, o magro, atormentado Brum, transformouse em um Brum diferente: mais alto, de ombros mais largos e um espesso bigode. Passava horas no subsolo do "Cavalo Branco", com sua flamejante mulher, bebendo cerveja. Ele, que jamais havia pronunciado uma palavra, falava com ela aos gritos, como se fosse surda. [...] [Brum] havia conseguido o impossível: reencarnar-se na figura de um pecuarista austríaco (TP, 154).
}

Esse homem, que se desvinculou de tudo o que Bruno chama "velho" (TP, 203), que sente nojo de sua encarnação anterior (TP, 203), que conseguiu uma "transfiguração sem resto", esse, que outrora não pronunciava palavra é, precisamente, o que conserva, ao preço da loucura, as palavras em sua nudez:

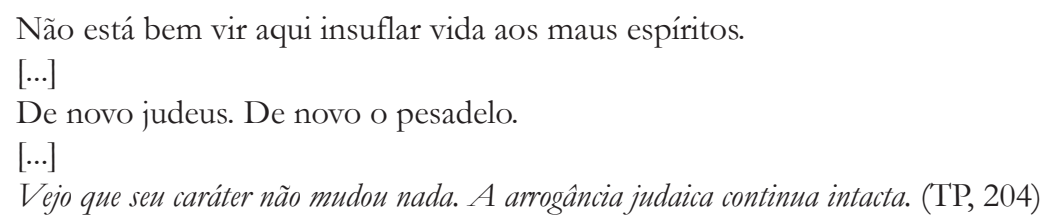

E quando Bruno o derruba com um empurrão, Brum diz, com voz sibilante: "Meu ódio dos judeus não conbece limites", e olha Bruno "como se não se tratasse de uma pessoa, mas de um fantasma”. Então Bruno decide partir, então "nenhuma lembrança havia nele, como se houvessem se entreverado sem deixar sequer uma mancha". 
São as próprias palavras que esta escritura persegue, nelas se detém, mas não por afã de reflexão metalingüística, e sim como deriva que, buscando uma língua, encontra palavras. E com elas fala em outra língua, uma língua explodida, vacilante, clandestina, que aparece - como a Shoah - como silêncio nas palavras. Dessas palavras são feitos os prodígios. Esses atemorizantes prodígios que se contavam nas aldeias sobre os judeus, o prodígio das palavras que se escrevem branco sobre branco em uma página muda, o prodígio que vocifera desde o começo (p. 11), para quem quiser ouvi-lo, uma voz inquietante que não cessa de interpelar mesmo depois de muitos anos: Ha'ein iehudim milvadí be'karón mejubad zeh? Haflé va’péle! - Por acaso não há mais judeus além de mim neste respeitável vagão? Que prodígio!

Notas

${ }^{1}$ Embora o iídiche e o judaico-espanhol sejam as mais conhecidas, o arraigado multilingüismo dos judeus presente já no par hebraico/aramaico da antiga Israel - germinou em um grande número de línguas judaicas. 2 "Dialeto hebraico", diz a Enciclopedia del idioma, de Martín Alonso (Madri: Aguilar, 1982); "corruptela do hebraico e do alemão antigo ou provincial", diz a Enciclopedia ilustrada Sopena (Barcelona, 1982); "língua dos judeus alemães", diz o Diccionario general ilustrado de la lengua española (Barcelona: Bibliograf, 1980). Citado por Tocker, Eliahu. "El ídish, país sin territorio", IDIOMANLA - Análisis de los idiomas del mundo, ano 2, n. 16, jul. 1993.

${ }^{3}$ A vigência do iídiche na América Latina - especialmente na Argentina - até meados dos anos 1960 ultrapassaria os limites deste trabalho. No entanto, é um traço a ser destacado em uma cultura em que o nacionalismo encontra seu campo mais fértil na defesa da língua nacional do assédio dos estrangeiros.

${ }^{4} \mathrm{Na}$ conferência de Czernowitz. Cf. Níger, Sh. "The Czernowitz Conference”, em Bilingualism in the History of Jewish Literature. University Press of America, 1984.

5 Zhargon: "jargão", termo de origem espanhola que significa barulho do piar dos pássaros, e chegou ao iídiche através do russo.

${ }^{6}$ Iluminismo judaico, surgido no século XVIII, cuja grande figura foi Moses Mendelssohn (1729-86).

${ }^{7}$ Movimento popular surgido no início do século XVII na Europa Oriental, que se converteu em um elemento fundamental da vida judaica oriental européia. Seu fundador foi Israel Báal Shem Tov (1700-60).

${ }^{8}$ Naomi Seidman. A marriage made in heaven. Berkeley: University of California Press, 1997.

9 Shtetl, iídish, lit.: "pequena cidade"; nome que se dava aos vilarejos judeus na Europa Oriental, âmbito privilegiado do iídiche.

${ }^{10}$ Shólem Aleijem, pseudônimo de Shólem Rabinovitch, escritor e humorista excepcional, chamado "filho da literatura iídiche". É um dos três grandes mestres da literatura iídiche moderna, junto com Méndele Mojer Sforim (chamado o avô da literatura em iídish) e Itzjok Leibush Péretz (o neto dessa literatura).

${ }^{11}$ Ver nota anterior.

${ }^{12}$ Sabra: fruto do cacto que - sendo espinhoso por fora e doce por dentro - condensa o ideal dos pioneiros, tendo se convertido por isso no apelativo dado aos nascidos em Israel.

${ }^{13}$ Shamir, Moshé - Be mo iadav (Com suas próprias mãos).

${ }^{14}$ A citação é paráfrase irônica do poema Promessa, de Abraham Shlonsky, que exige, em relação à Shoah, "recordar tudo e não esquecer nada".

${ }^{15}$ Elik é um diminutivo do nome hebraico Eliahu, que soa “diaspórico” pela semelhança do diminutivo com o sufixo eslavo nik, tão comum no iídiche.

${ }^{16}$ Aharón Appelfeldm, Historia de una vida. Barcelona: Editorial Península, 2004.

17 "Não se fala uma língua materna, ela simplesmente flui. Com uma língua adquirida, há que estar em alerta permanente, protegendo-a de interferências estrangeiras. Até hoje temo que a língua se perca. Às vezes acordo e parece que o hebraico - a língua que adquiri com grande esforço - se perde, desaparece".

${ }^{18}$ Atualmente faz parte da Ucrânia. 
${ }^{19}$ Appelfeld, Aharón. El maestro. Ensaio dedicado a Dov Sadán por ocasião de seu $75^{\circ}$ aniversário. Citado por Dan Iaor no congresso De Czernowitz a Jerusalén, realizado na Universidade Hebraica de Jerusalém.

${ }^{20}$ Prof. Dov Sadán, primeiro diretor do Departamento de Iídiche da Universidade Hebraica de Jerusalém, criado em 1952, a quem reconhece como seu mestre junto com Leib Rochman. Cf. nota 19.

${ }^{21}$ Appelfeld, Aharón. Tor Ha'Plaot. $7^{\text {a }}$ ed. Hotza'at Ha'Kibutz Ha'Meujad - Hakibbutz Hameuchad Publishing House, 2001. Há tradução castelhana, realizada por Etty de Hoter: Tiempos prodigiosos. Jerusalém: La Semana Publicaciones Ltda., 1980. As citações do texto acompanhadas pelas iniciais TP e número de página remetem a esta versão. As que apresentam apenas o número de página remetem à versão hebraica e a tradução é minha.

${ }^{22}$ Schwartz, Ygal. Aharón Appelfeld - From Individual Lament to Tribal Eternity. Hannover; Londres: University Press of New England, 2001.

${ }^{23}$ Diz Mallarmé: "Um poema não se escreve com idéias, se escreve com palavras".

${ }^{24}$ Cf. Roth, Philip. El oficio: un escritor, sus colegas y sus obras. Barcelona: Seix Barral, 2003.

${ }^{25}$ Ver nota 10.

${ }^{26}$ Thomas Garrigue Masaryk: 1850-1937: Filósofo e estadista tcheco, primeiro presidente da Tchecoslováquia. De origem humilde, Masaryk cresceu imbuído do anti-semitismo católico popular em seu meio, mas, por influência de seus colegas de estudos, mudou de opinião. Sustentava, em divergência com Marx, que os judeus são um povo homogêneo, mesmo que tenham renunciado a seu idioma. Entendia o sionismo em um sentido moral e considerava impossível ser, ao mesmo tempo, cristão e anti-semita. Combateu o anti-semitismo com exemplo pessoal, visitou a Palestina e a então recém-fundada Universidade Hebraica de Jerusalém, e em 1935 recebeu o título de cidadão honorário da cidade de Tel Aviv.

27 "O endereço no verso do envelope: Masaryk. 5." (p. 110).

${ }^{28}$ Nome de um shtetl imaginário na obra de Shólem Aleijem. Uma tradução aproximada de Kasrílevke seria: Mendigolândia. Ver Kasrílevke, ciudad chica e Kasrílevke, ciudad grande, ambos da Acervo Cultural Editora, 1950.

29 "Cada cidade teve, ao que parece, seu Januscz Korczak. Entre nós, foi o diretor do abrigo, o professor Gutsman, quem conduziu os meninos cegos à estação". Cf. Historia de una vida, op. cit.

30 Shtetl, iídiche, lit.: "pequena cidade"; nome que se dava aos vilarejos judaicos na Europa Oriental, âmbito privilegiado do iídiche.

${ }^{31}$ Ver, por exemplo, "La muerte de un klezmer", de Y.L. Péretz: "Até o verdadeiro especialista, o curandeiro do hekdesh, havia dado seu veredito. Não havia nada a fazer...".

${ }^{32}$ Gilman, Sander. "The Creation of the Schlemiel", em Jewish Self-Hatred. Baltimore; Londres: Johns Hopkins University Press, 1986.

33 Idem.

${ }^{34}$ Anunciada já desde o começo pelo olhar vigilante do guarda que convida a registrarem-se estrangeiros e cidadãos austríacos que não sejam cristãos de nascimento.

${ }^{35}$ Bar Mitzvá: "filho dos preceitos", assim se denomina o homem judeu que, ao chegar aos treze anos, tornase responsável pelas próprias transgressões. Na cerimônia correspondente, o menino é chamado pela primeira vez a ler a Torá.

\section{Bibliografia}

Appelfeld, Aharón. Tor Ha'Plaot. $7^{\text {a }}$ ed. Hotza'at Ha'Kibutz Ha'Meujad - Kakibbutz Hameuchad Publishing House, 2001.

. Tiempos prodigiosos (trad.: Etty de Hotel). Jerusalém: La Semana Publicaciones Ltda., 1980.

El maestro (ensaio em homenagem ao aniversário de Dov Sadán).

. Historia de una vida. Barcelona: Editorial Península, 2004.

Gilman, Sander. "The Creation of the Schlemiel", em Jewish Self-Hatred, Anti-Semitism and the Hidden Language of the Jews. Baltimore; Londres: Johns Hopkins University Press, 1986.

Niger, Shmuel. "The Czernowitz Conference", em Bilingualism in the History of Jewish Literature. University Press of America, 1984.

Roth, Philip. El oficio: un escritor, sus colegas y sus obras. Barcelona: Seix Barral, 2003. 
Remate de Males - 26(1) - jan./jun. 2006

Schwartz, Ygal. Aharón Appelfeld - From Individual Lament to Tribal Eternity. Hannover; Londres: University Press of New England, 2001.

Seidman, Naomi. A marriage made in heaven. Berkeley: University of California Press, 1997.

Tradução de Gênese Andrade 